OPEN ACCESS

Edited by: Heriberto Rodriguez-Martinez, Linköping University, Sweden

Reviewed by:

Szabolcs T. Nagy,

University of Pannonia, Hungary Jose Antonio Tapia,

University of Extremadura, Spain

${ }^{*}$ Correspondence:

Khalid El Allali

k.elallali@iav.ac.ma

Specialty section:

This article was submitted to Animal Reproduction -

Theriogenology,

a section of the journal

Frontiers in Veterinary Science

Received: 05 April 2017

Accepted: 12 June 2017

Published: 30 June 2017

Citation:

El Allali K, El Bousmaki N, Ainani H and Simonneaux V (2017) Effect of

the Camelid's Seminal Plasma

Ovulation-Inducing Factor/ $\beta$-NGF:

A Kisspeptin Target Hypothesis.

Front. Vet. Sci. 4:99.

doi: 10.3389/fvets.2017.00099

\section{Effect of the Camelid's Seminal Plasma Ovulation-Inducing Factor/B-NGF: A Kisspeptin Target Hypothesis}

\author{
Khalid El Allali ${ }^{1 *}$, Najlae El Bousmaki ${ }^{1,2}$, Hassan Ainani ${ }^{1,2}$ and Valérie Simonneaux ${ }^{2}$ \\ ${ }^{1}$ Comparative Anatomy Unit/URAC49, Department of Biological and Pharmaceutical Veterinary Sciences, Hassan II \\ Agronomy and Veterinary Medicine Institute, Rabat, Morocco, ${ }^{2}$ Department of Neurobiology of Rhythms, CNRS UPR 3212 , \\ Institute of Cellular and Integrative Neurosciences, University of Strasbourg, Strasbourg, France
}

Female mammals are classified into spontaneous and induced ovulators based on the mechanism eliciting ovulation. Ovulation in spontaneous species (e.g., human, sheep, cattle, horse, pigs, and most rodents) occurs at regular intervals and depends upon the circulating estradiol. However, in induced ovulators (e.g., rabbits, ferrets, cats, and camelids), ovulation is associated with coitus. In the later, various factors have been proposed to trigger ovulation, including auditory, visual, olfactory, and mechanic stimuli. However, other studies have identified a biochemical component in the semen of induced ovulators responsible for the induction of ovulation and named accordingly ovulation-inducing factor (OIF). In camelids, intramuscular or intrauterine administration of seminal plasma (SP) was shown to induce the preovulatory luteinizing hormone (LH) surge followed by ovulation and subsequent formation of corpus luteum. Recently, this OIF has been identified from SP as a neurotrophin, the $\beta$ subunit of nerve growth factor ( $\beta$-NGF). $\beta$-NGF is well known as promoting neuron survival and growth, but in this case, it appears to induce ovulation through an endocrine mode of action. Indeed, $\beta$-NGF may be absorbed through the endometrium to be conveyed, via the blood stream, to the central structures regulating the LH preovulatory surge. In this review, we provide a summary of the most relevant results obtained in the field, and we propose a working hypothesis for the central action of $\beta$-NGF based on our recent demonstration of the presence of neurons expressing kisspeptin, a potent stimulator of $\mathrm{GnRH} / \mathrm{LH}$, in the camel hypothalamus.

Keywords: ovulation-inducing factor, $\beta$-NGF, camelids, camel, ovulation, seminal plasma, kisspeptin

\section{INTRODUCTION}

Ovulation is a critical event in the reproductive function in all female mammals. Gonadotropinreleasing hormone $(\mathrm{GnRH})$ is the key regulatory neuroendocrine pathway implicated in the regulation of ovulation. Based on the biological process that triggers the release of GnRH, two categories of species are classified as follows: spontaneous and induced ovulators. In animals considered as spontaneous ovulators (e.g., women, cattle, horses, sheep, goat, pigs, monkeys, and most rodents), ovulation occurs at regular intervals. The ovarian follicular dynamic leads to the emergence of one or 
more dominant follicles (depending of species been monoparous or multiparous), which increases the systemic concentration of estradiol. High estradiol concentration switches its negative to a positive feedback, which is permissive for the activation of GnRH release into the portal blood. Recent studies have demonstrated that hypothalamic neurons expressing kisspeptin (Kp) are critical to integrate the negative-to-positive switching effect of estradiol and to activate GnRH release (1). GnRH in turn triggers a strong and transitory release of luteinizing hormone (LH) (LH surge) from the gonadotrophs of the pituitary gland (2). This marked increase in circulating LH activates a whole cascade of inflammatory and proteolytic responses leading to the rupture of the dominant follicular boundary wall and the extrusion of the oocyte with its cumulus oophorus (3-5). In induced (also called reflex) ovulators (e.g., rabbit, Bactrian and dromedary camel, llama, alpaca, cat, ferret, etc.), the signals generated by copulatory stimulation during mating appear sufficient to induce ovulation while the positive feedback action of estradiol is reduced or absent $(6,7)$. It has been suggested that genital-somatosensory signals generated by penile intromission during copulation activate neural circuitries, mainly noradrenergic neurons, in the midbrain and brainstem to promote GnRH release (6). Several other stimuli including emotional, olfactory, auditory, visual, and tactile signals have also been assumed to facilitate ovulation $(8,9)$. The purification of a biochemical component from camelid's semen, which was able to trigger ovulation, led to the concept of an "ovulation-inducing factor (OIF)" in the seminal plasma (SP) of induced ovulators $(10,11)$. The existence of this OIF was then confirmed in several other studies (12-16) and recently identified by Ratto et al. (17) as a neurotrophin: $\beta$ subunit of nerve growth factor ( $\beta$-NGF).

This review presents the history and discovery of OIF/ $\beta$ NGF, highlights recent findings regarding its biochemical identification and sites of action and proposes hypothesis for the mechanisms through which the seminal $\beta$-NGF acts on the central nervous systems of female induced ovulators, mainly camelids.

\section{OIF IN THE SP OF CAMELIDS BREAKS OLD DOGMA}

The understanding of the mechanism by which ovulation is initiated in induced ovulators was the purpose of different studies since the 1960s. The first evidence of the existence of an induced process of ovulation in camelids was reported in alpacas where authors documented that mounting accompanied by intromission was necessary to provide adequate stimulation of LH release and the subsequent ovulation $(8,18,19)$. Later on, Shalash and Nawito (20) observed that ovulation also required mating in dromedary and Bactrian camels and suggested that coitus, mechanical or electrical stimuli of the cervix would be essential for ovulation. From these early studies, it was believed that physical stimulation of the genitalia during copulation is the primary trigger for inducing ovulation in camelids species. This dogma lasted until 1985 when two remarkable studies published in the same Journal of Reproduction and Fertility $(10,11)$ reported the ovulation-inducing effect of semen in Bactrian camel. Both studies showed that the single intramuscular or intravaginal administration of male SP induced a surge in LH followed by ovulation. In their study, Chen et al. (10) compared the effect of intravaginal administration of (1) fresh and frozen semen, (2) SP, (3) washed spermatozoa, and (4) intramuscular injection of SP of bull, on ovulation rate in female Bactrian susceptible to ovulate (follicles diameter $\geq 1.2 \mathrm{~cm}$ ). Their results showed that ovulation occurred in 28/32 females inseminated with whole semen, independently of whether the semen contained or not frozen spermatozoa. Contrastingly, none of the female inseminated with washed spermatozoa ovulated. Furthermore, ovulation was observed in 6/8 females inseminated with Bactrian SP and in 2/7 female injected with bull SP. In all case, the timing of ovulation was similar to that observed following natural mating (36-48 h later). In the other study, Xu et al. (11) found similar results and further reported that $4 \mathrm{~h}$ after intravaginal deposition of semen, an LH surge occurred followed by ovulation 36-48 h later, thus indicating that the semen-induced ovulation depends upon an LH surge.

Further studies, especially in Chile and Canada, confirmed the robust ovulatory effect of SP in llamas and alpacas. A single intramuscular dose of SP ( $<1 / 4$ of an ejaculate) of llamas or alpacas induced an increase in plasma LH concentrations and ovulation in more than $90 \%$ of females (13). In a recent work, Berland et al. (21) not only confirmed that intrauterine infusion of $5 \mathrm{ml}$ SP induces ovulation in llamas but also that ovulation depends more on this chemical signals than on physical stimulation or penile intromission as ovulation rate was of $0 \%$ when mating was performed by urethrostomized male, as compared to $85.7 \%$ when mating was done by intact male.

From these studies, authors suggested the presence of a potent factor in the SP of induced ovulators responsible for the induction of ovulation and named it accordingly OIF or "GnRH-like factor." This concept was gradually accepted and many scientists then suggested that induced ovulation is a multifactorial event occurring as a consequence of several signals: mechanical stimuli of coitus, male effect, and most importantly OIF in the SP (22-25).

\section{COMPARATIVE APPROACH OF THE OIF VERSUS GnRH EFFECTS}

So far, the described effect of OIF appears similar to that of $\mathrm{GnRH}$ used for the control of reproduction in camelids $(26,27)$ leading to the question of similar mechanisms of action of both molecules. A comparative study performed by Adams et al. (13) in female llama showed that intramuscular injection of SP induced a higher ovulation rate (93\%) than GnRH (83\%). Interestingly, the increase in plasma $\mathrm{LH}$ concentration observed in SP treated female was faster but more prolonged as compared to the ones treated by $\mathrm{GnRH}$ : a significant increase in plasma $\mathrm{LH}$ concentration was seen 15 min after treatment with SP and 75 min after injection of $\mathrm{GnRH}$; the maximum was reached after $2 \mathrm{~h}$ with SP as compared to $1 \mathrm{~h}$ with $\mathrm{GnRH}$; and finally, the decrease was delayed by $2.5 \mathrm{~h}$ in the SP treated group 
(Figure 1A). Furthermore, the corpus luteum (CL) showed a greater diameter, regressed later, and produced more than two times progesterone in SP treated group as compared to the $\mathrm{GnRH}$ injected group (Figure 1B). Interestingly, the pattern of SP-induced LH surge (13) is very similar to that described in response to natural mating $(28,29)$. A careful reading of figures of another study comparing the effect of purified OIF to a GnRH analog (Buserelin) in dromedary females (30) showed that progesterone secretion subsequent to ovulation is prolonged in OIF-treated group as compared to $\mathrm{GnRH}$ analog group. This seems to indicate that in female camel also, the luteotrophic activity of OIF is more important than that of GnRH.

Different studies (31-33) demonstrated that as for $\mathrm{GnRH}$, the OIF shows a dose-response effect on circulating concentration of LH and the incidence of ovulation in llamas and alpaca. However, unlike GnRH, purified OIF showed a dose-response relationship for the $\mathrm{CL}$ diameter and plasma progesterone concentrations $(31,33)$. This indicates a possible luteotrophic effect of OIF, which is independent of the mechanisms involved by GnRH.

The important luteogenesis effect of OIF/SP can be explained by its local effect at the level of the CL. Indeed, it was reported that its administration induces an important angiogenesis with a high blood flow, promoting the formation of the CL (34-36).
Altogether, these results indicate that $\mathrm{OIF}$ and $\mathrm{GnRH}$ are two different molecules because OIF effect is more important than that of GnRH and they affect pituitary LH release differently.

\section{ISOLATION AND PURIFICATION OF THE OIF}

Important effort has been conducted to characterize the biochemical nature of the semen OIF. A preliminary study carried out in Bactrian camel reported that OIF bioactivity disappears when SP is subjected to trypsin digestion, indicating its proteic nature (37). Further studies were performed to purify and characterize OIF in Bactrian camel $(12,38,39)$, llamas $(16,40)$, and recently in dromedary camel (30). In the exhaustive study conducted by Pan et al. (38), proteins of Bactrian camel SP were compared with those of cattle, sheep, and swine using SDS-PAGE analysis. The smallest difference regarding the protein molecular weights was observed for a pair of proteins of camel and cattle SPs, with, respectively, 19.431 and $19.761 \mathrm{kDa}$. The $19.431 \mathrm{kDa}$ proteic camel extract was eluted along a DEAE-cellulose column into seven fractions. Of all fractions injected in the muscle of female camels only the $\mathrm{L}_{2}$ fraction induced ovulation. Further $\mathrm{L}_{2-2}$ then $\mathrm{L}_{2-2-2}$ subfractions were identified according to their ability to
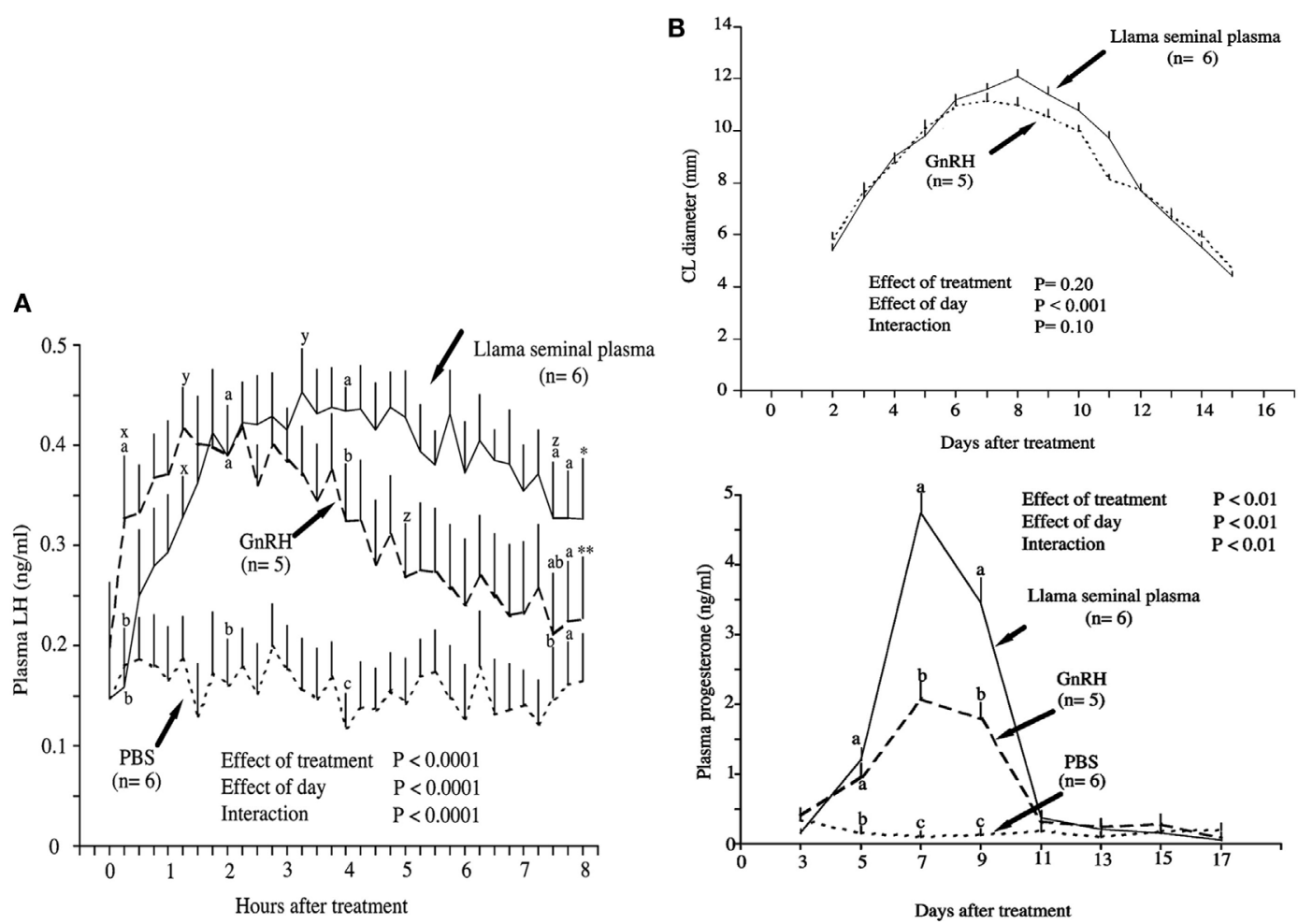

FIGURE 1 | Effect of intramuscular treatment of female llamas with llama seminal plasma, gonadotropin-releasing hormone (GnRH), or phosphate-buffered saline (PBS). The effect was studied on (A) plasma luteinizing hormone concentrations and (B) corpus luteum diameter and plasma progesterone concentrations. Data are represented as mean \pm SEM. ${ }^{a, b, c}$ On a given day, values with no common superscript are different among groups $(P<0.05)$. ${ }^{\times}$Within group, the first increase from pretreatment (time 0$)$ concentration $(P<0.05)$. 'Within group, the maximum concentration $(P<0.05)$. ${ }^{2}$ Within group, the first decrease from maximum concentration $(P<0.05)$. ${ }^{*}$ Within group, the last value is higher than the pretreatment value $(P<0.05)$. ${ }^{*}$ Within group, the last value is not different from the pretreatment value $(P=0.9)$ [modified from Ref. (13)]. 
induce ovulation following its intravenous injection in female camel and mice. This later $\mathrm{L}_{2-2-2}$ fraction of $8.360 \mathrm{kDa}$ consisted of two components, the first named $\mathrm{OIF}_{1}$, represented a bioactive sequence of 19 amino acids, the second $\mathrm{OIF}_{2}$, represented a conserved sequence of 57 amino acids. Using similar approaches, Zhao et al. (12) and Li and Zhao (39) isolated proteic fractions (L3 and F3, F5, respectively) able to stimulate LH but not FSH release (Figure 2).

In another series of experiments, Ratto et al. (16) attempted to inhibit OIF biological activity using the following: (1) filtration with nominal molecular mass cutoff $-30^{\circ} \mathrm{kDa}$, (2) enzymatic digestion with proteinase $\mathrm{K}$, (3) filtration with charcoal dextran and heat treatment $\left(12 \mathrm{~h}\right.$ at $38^{\circ} \mathrm{C}$ or $1 \mathrm{~h}$ at $\left.65^{\circ} \mathrm{C}\right)$, and (4) treatment with pronase $\mathrm{E}$, a more aggressive enzyme. The treatment effect was challenged by testing intramuscular injections of resulting fractions in female llama. Llama ovulation bioassay indicated that OIF is a protein with a molecular mass larger than $30 \mathrm{kDa}$ and that its bioactivity is inhibited by pronase $\mathrm{E}$ because such digestion resulted in proteins $<15 \mathrm{kDa}$, but not by proteinase $\mathrm{K}$ even its digestion gave proteins $<19 \mathrm{kDa}$ (Table 1). In a followup study, Ratto et al. (40) isolated a protein C2 with a molecular mass of $13.221 \mathrm{kDa}$, which was still bioactive. This purified $\mathrm{C}_{2}$ was able to elicit a preovulatory LH surge followed by high rate of ovulation (>90\%), similarly to SP. Furthermore, the CL attained a greater diameter and secreted more progesterone in $\mathrm{C}_{2}$ - than in SP-treated animals (Figure 3). Altogether, these results suggest that OIF is a large proteic complex made of different subunits with only a part being bioactive.

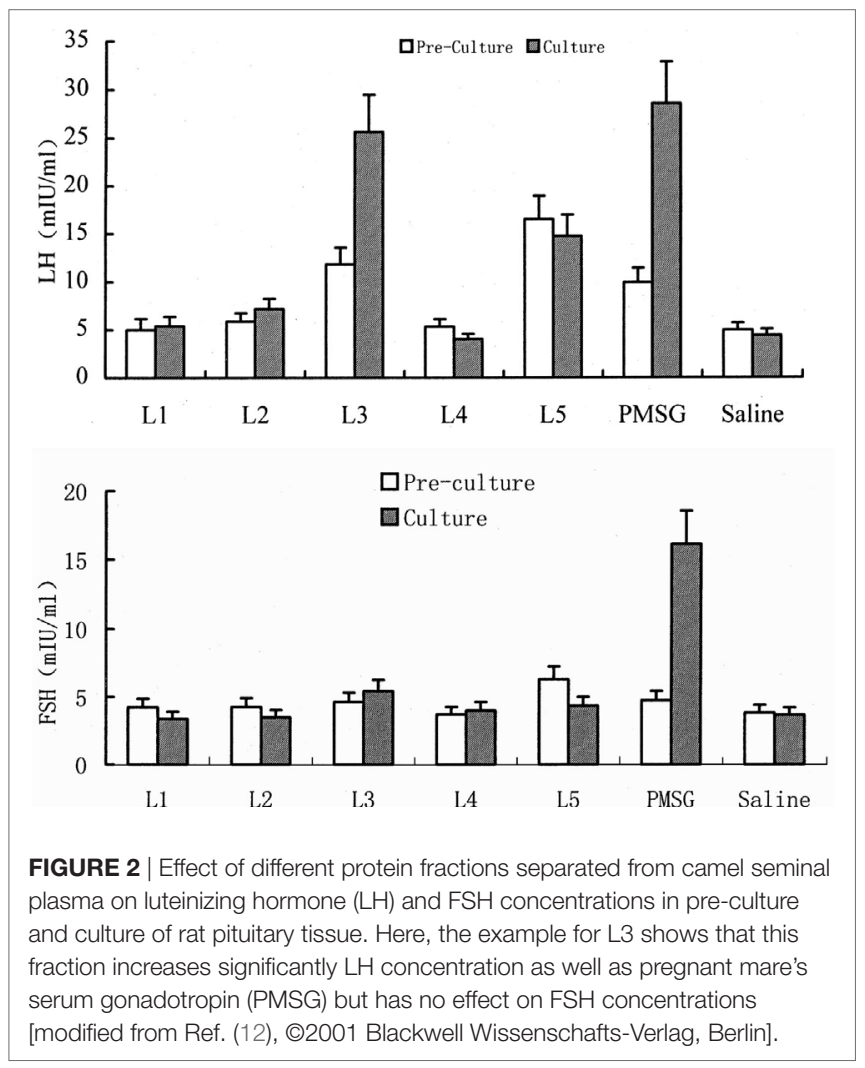

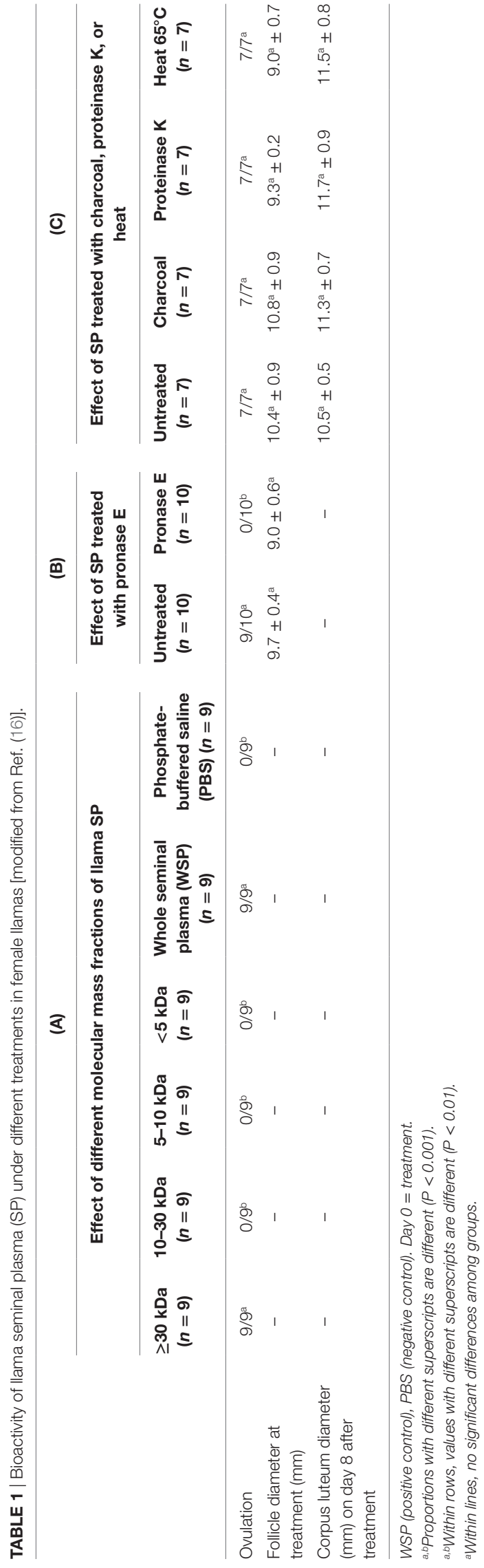




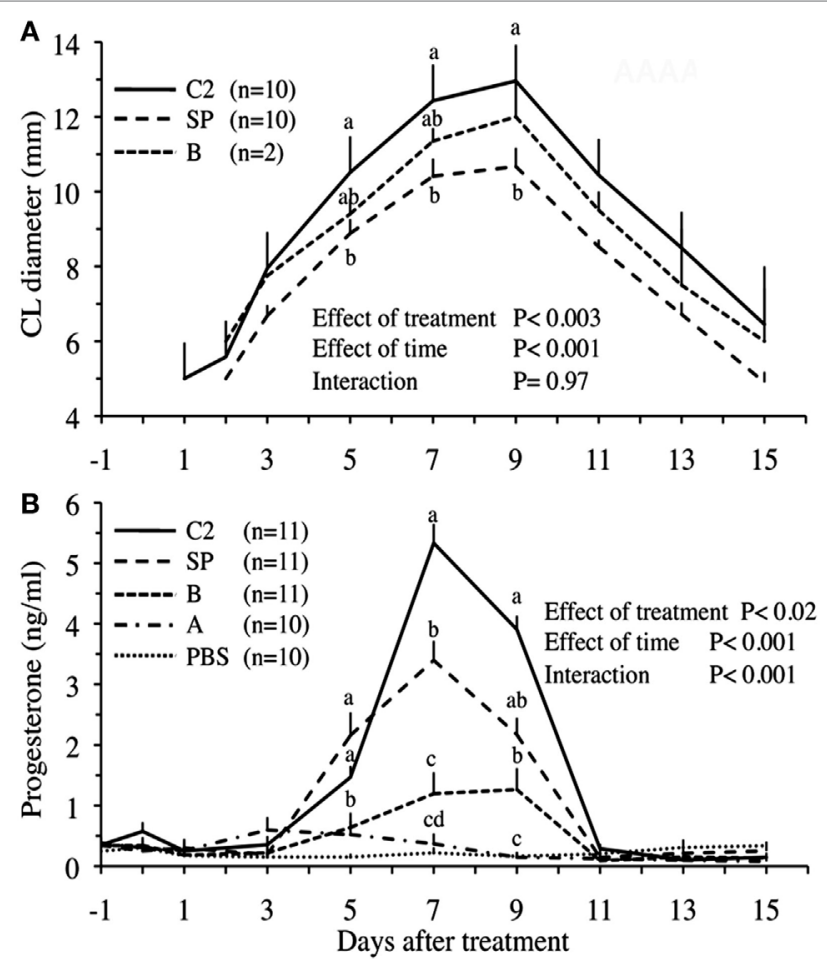

FIGURE 3 | Corpus luteum (CL) diameter (A) and plasma progesterone concentrations (B) in llama females, which received different protein fractions separated from llama seminal plasma (SP). Administration concerned, whole SP (positive control), fractions A or B (isolated by hydroxylapatite column chromatography), fraction C2 (isolated by gel filtration chromatography), or phosphate-buffered saline (PBS, negative control). a,b,c,dWithin days, values with no common superscript are different $(P<0.05)$ [modified from Ratto et al. (40)].

\section{BIOCHEMICAL NATURE OF THE OIF: $\beta$-NGF}

Ratto et al. (17) further used different techniques to identify the biochemical nature of OIF from llama's SP. They observed that the bioactive $\mathrm{C}_{2}$ fraction has an exact molecular mass of $13.221 \mathrm{kDa}$ with 12-23 amino acid sequences similar to the human, porcine, bovine, and murine sequences of $\beta$ subunit of nerve growth factor $(\beta-\mathrm{NGF})$. Moreover, structure analysis and superposition of OIF composition with $\beta$-NGF of other species using X-ray diffraction revealed important structural similarities. They further found that the purified $\mathrm{C}_{2}$ fraction was able to induce neurite outgrowth and upregulated the mRNA expression of the NGF receptor tyrosine kinase receptor (TrKA) similarly to NGF treatment (17). Using another in vivo bioassay, they reported that injection of fraction $\mathrm{C}_{2}$ or mouse $\beta$-NGF leads to similar ovulation rate. Finally, they confirmed the presence of $\beta$-NGF in the SP of llamas using a western blot analysis with a polyclonal antibody against $\beta$-NGF. Altogether, this decisive study of Ratto et al. (17) pointed OIF as being $\beta$-NGF. Additional studies confirmed this observation. Thus, in alpaca an intramuscular administration of $\beta$-NGF induced ovulation in $80 \%$ of female (41), and $\beta$-NGF was found extremely abundant in alpaca and dromedary SP $(41,42)$. Furthermore, in this later species, recent purification of SP showed two protein peaks, P1 and P2. The P2 peak that contains a major protein with a molecular weight of $14 \mathrm{kDa}$ was identified as Cam- $\beta$-NGF. Its intramuscular injection induced ovulation in $100 \%$ of females (30).

In addition to camelids, high concentrations of $\beta$-NGF have also been found in the SP of other induced ovulators. In rabbits, for example, $\beta$-NGF protein was found in the SP by western blot, and $\beta$-NGF mRNA was found in reproductive organs, including prostate, testis, and seminal glands (43-45). However, the ovulation-inducing effect of $\beta$-NGF was found weak in this species since injection of SP or murine $\beta$-NGF did not increase plasma $\mathrm{LH}$-induced poor ovulation rates $(43,46,47)$. Therefore, the significance of $\beta$-NGF in inducing ovulation may differ among induced ovulators.

$\beta$-NGF consists of a family of neurotrophin proteins, which play a role on neuron survival and differentiation in the peripheral and central nervous system and in the functional integrity of cholinergic neurons $(48,49)$. $\beta$-NGF is also largely present in peripheral tissues especially in salivary gland. The presence of $\beta$-NGF in male genital secretion is not a surprising finding since already in 1979, it was found in the guinea pig prostate (50) then in the prostate of rabbit, pig, and bull (51). Later, it was shown that bovine SP contains a high level of $\beta$-NGF (52) and that it can be produced by seminal vesicles (53) or epididymis (54).

The concentration of $\beta$-NGF is particularly high in the SP of llama where it reaches approximately $4-12 \mathrm{mg} / \mathrm{ml}$, thus $15-30 \%$ of total protein $(31,41)$ whereas its concentration is $0.7 \mathrm{mg} / \mathrm{ml}$ in the bovine SP (52). Other studies confirmed that SP $\beta$-NGF concentration is greater in induced as compared to spontaneous ovulators. Such difference may explain the differential effect of $\beta$-NGF between these two categories of breeders. Indeed, llama's SP induces ovulation in $78 \%$ of prepubertal mice (55) while purified $\beta$-NGF from cattle did not induce ovulation, although it accelerated the generation of a new follicular wave, influenced the dynamics in mature follicules and affected FSH and progesterone levels (56). Similarly, intramuscular injection of $2 \mathrm{ml}$ of llama SP induced ovulation in $100 \%$ of llama females while $2 \mathrm{ml}$ bull SP induced ovulation in only $26 \%$ of female llamas (15). Therefore, $\beta$-NGF is present in the SP of different mammalian species but at higher levels in induced ovulators.

\section{MECHANISMS OF ACTION OF SP $\beta$-NGF: LOCAL VERSUS SYSTEMIC ANALYSIS}

A local effect of $\beta$-NGF on ovaries was considered in spontaneous ovulators because it appears required for the development of primary and secondary follicles and for incorporating oocytes into the follicular structure, a process occurring independently of pituitary gonadotropins (48). In the female rat, $\beta$-NGF and its specific receptor (TrkA) are involved in the intracellular signaling pathways leading to follicular rupture (57-59) and both are upregulated in the theca cells of antral follicles during the preovulatory period, resulting in amplification of ovarian steroidogenesis (59). In addition, $\beta$-NGF, TrkA, and a non-specific receptors ( $\mathrm{p} 75$ ) 
are found in fetal or adult ovaries of human (60), mice (48), and guinea pig (61). Furthermore, recent data in cattle suggest that $\beta$-NGF exerts its luteotrophic effect by acting locally at the level of ovaries through TrkA located in the dominant follicle and the developing of CL [Figure 4; $(36,62)$ ]. These observations are in favor of a significant role of $\beta$-NGF on ovaries of several species.

In female alpaca, the ovulation rate depends on the dose and site of deposition of SP $(14,36)$. Indeed, ovulation rate is $0 \%$ after $1 \mathrm{ml}$ infusion in the uterine body ( $41 \%$ after $2 \mathrm{ml}$ infusion in the uterine horns; $67 \%$ if an endometrial curettage is made before intrauterine deposition and $93 \%$ after an intramuscular injection) (Table 2). These findings suggest that genital mucosa may prevent $\beta$-NGF absorption. In this regard, copulation in alpacas and llamas is a $30-50 \mathrm{~min}$ long event with an intrauterine ejaculation suggesting that in natural mating $\beta$-NGF absorption from SP is probably facilitated by the hyperemia of the excoriated endometrium resulting from repeated abrasion by penis $(14,19,28,63)$. Taken together, these findings are consistent with the hypothesis

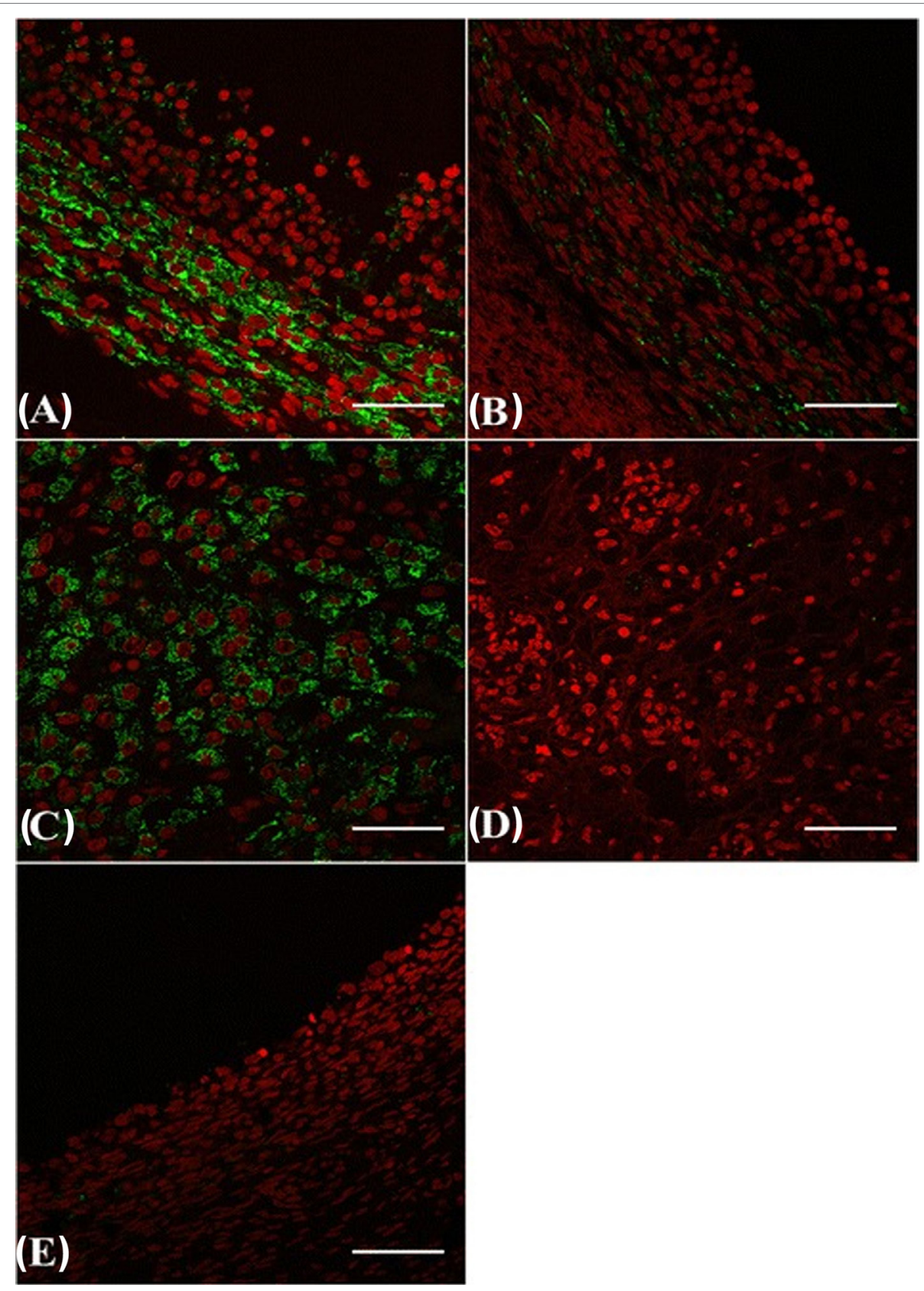

FIGURE 4 | $\beta$-NGF-specific receptor TrkA immunofluorescence labeling (green) in the ovary [follicles and the corpus luteum (CL)] of cattle. Dominant follicle (A), subordinate follicle (B), CL (C), CL from the previous cycle (D), and regressing dominant follicle from the previous cycle (E). Red: pseudo-color for nuclear counterstain. Scale bar $=50 \mu \mathrm{m}$ [from Ref. (62)]. 
TABLE 2 | Endometrial curettage effect on the ovulation rate and the formation of follicle and corpus luteum (CL) in female alpacas after intrauterine infusion with alpaca seminal plasma (SP).

\begin{tabular}{|c|c|c|c|c|c|c|}
\hline & \multicolumn{2}{|c|}{ Intramuscular } & \multicolumn{2}{|c|}{ Intrauterine } & \multicolumn{2}{|c|}{ Intrauterine with curettage } \\
\hline & SP & $\begin{array}{l}\text { Phosphate-buffered } \\
\text { saline (PBS) }\end{array}$ & SP & PBS & SP & PBS \\
\hline Follicle diameter at treatment $(\mathrm{mm})^{\star}$ & $8.0 \pm 0.3(n=15)$ & $8.2 \pm 0.3(n=15)$ & $8.1 \pm 0.3(n=17)$ & $8.0 \pm 0.3(n=15)$ & $8.3 \pm 0.2(n=15)$ & $8.4 \pm 0.3(n=15)$ \\
\hline Ovulation rate (\%) & $14 / 15^{\mathrm{a}}(93 \%)$ & $0 / 15^{\mathrm{c}}(0 \%)$ & $7 / 17^{\mathrm{b}}(41 \%)$ & $0 / 15^{\mathrm{c}}(0 \%)$ & $10 / 15^{\mathrm{a}, \mathrm{b}}(67 \%)$ & $0 / 15^{\mathrm{c}}(0 \%)$ \\
\hline 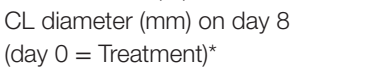 & $9.3 \pm 0.4(n=4)$ & - & $9.5 \pm 0.3(n=7)$ & - & $9.4 \pm 0.4(n=10)$ & - \\
\hline
\end{tabular}

Data are presented as mean \pm SEM (14).

*No difference among groups $(P \geq 0.9)$.

${ }_{a, b, c}$ Proportions with different superscript are different $(P<0.001)$.

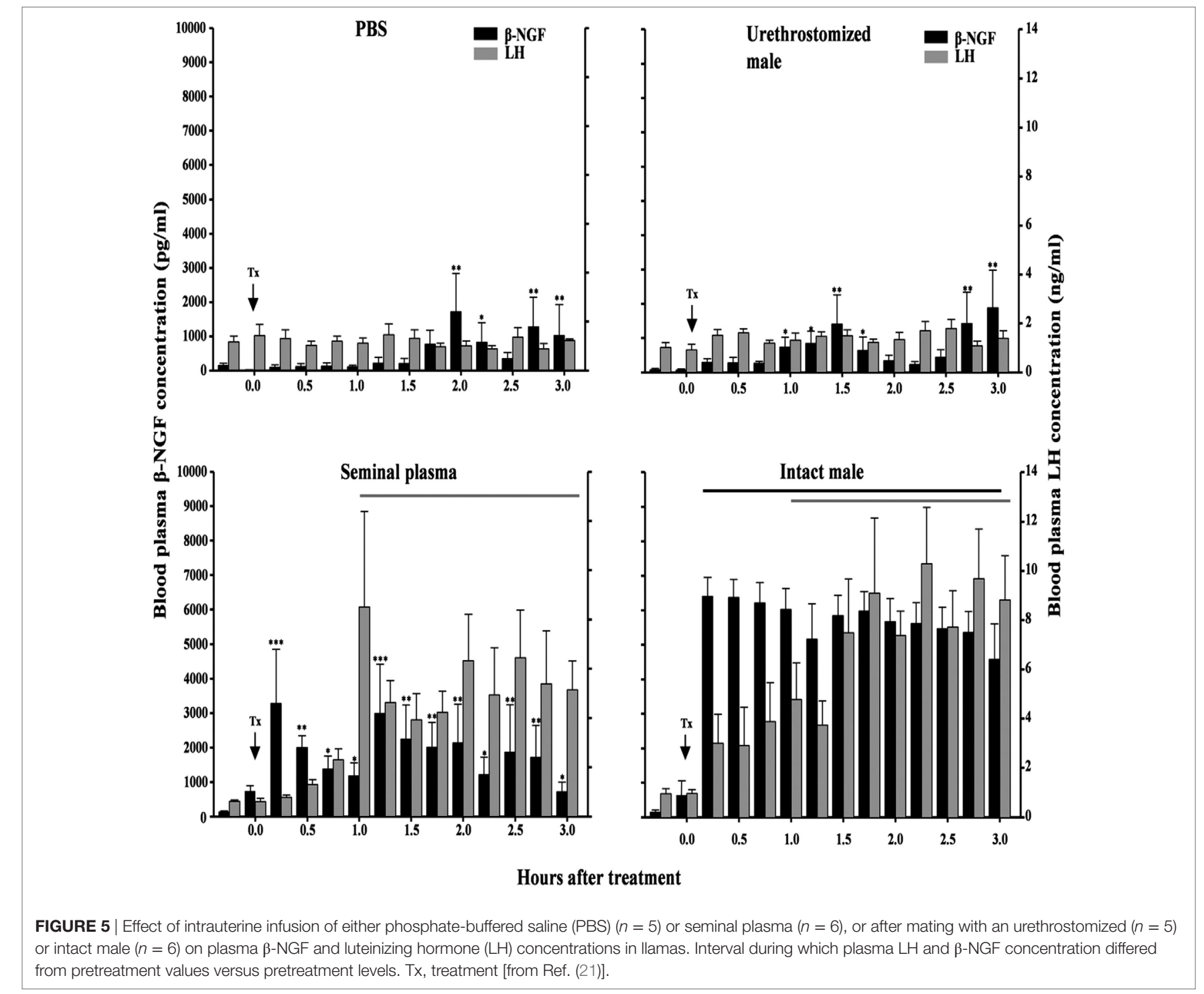

that $\beta$-NGF exerts its effect via a systemic rather than a local route, an hypothesis confirmed by the study of Berland et al. (21). In this study, blood plasma $\beta$-NGF level was measured in four groups of female llamas as follows: (1) receiving intrauterine infusion of SP,
(2) receiving intrauterine infusion of PBS, (3) mated to an intact male, and (4) mated to urethrostomized male. Female llamas mated with an intact male or receiving an intrauterine infusion of SP showed a large increase in circulating $\beta$-NGF already $15 \mathrm{~min}$ 
after treatment while the two other groups displayed low $\beta$-NGF levels (Figure 5). Authors also reported that ovulation depended on this elevated plasmatic $\beta$-NGF levels as only female mated with an intact male or given intrauterine infusion displayed a preovulatory surge of $\mathrm{LH}$ and ovulated. These new findings are very important since they demonstrated that SP $\beta$-NGF deposited in the uterus is absorbed within the general circulation and is possibly conveyed toward the central nervous system to induce a preovulatory LH surge.

\section{IDENTIFICATION OF THE $\beta$-NGF CENTRAL TARGET(s): THE Kp NEURON HYPOTHESIS}

Circulating $\beta$-NGF can induce LH secretion by a direct effect on the pituitary gonadotrophs or upstream in the central structures like GnRH neurons. Direct effect of $\beta$-NGF on cultured

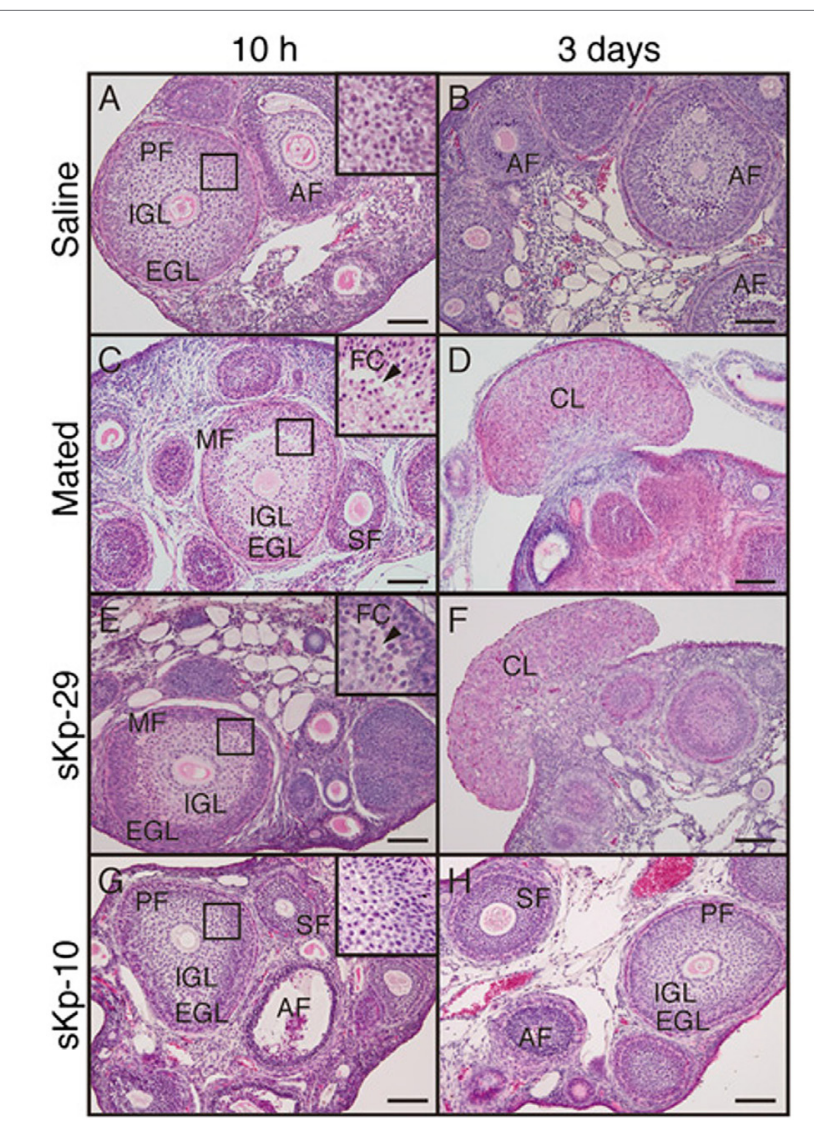

FIGURE 6 | Effects of kisspeptin (sKp-29 and sKp-10) injections on development and formation of follicular and CL in an induced ovulator, the musk shrew. Photomicrographs are of classical histology of ovaries stained with H\&E. (C,D) Females mated, (A,B) injected with saline, (E,F) injected with sKp-29, (G,H) sKp-10. Photographs were taken $10 \mathrm{~h}(\mathbf{A}, \mathbf{C}, \mathbf{E}, \mathbf{G})$ or 3 days $\mathbf{( B , D , F , H )}$ after the onset of mating or injection. A slit-like FC (arrowheads) in ovarian follicles at $10 \mathrm{~h}$ and fungiform corpora lutea in the ovary at 3 days were observed in mated and sKp-29-injected females. Insets show the boxed area in each panel at higher magnification. AF, atretic follicle; $C L$, corpus luteum; EGL, extra granulosa layer; FC, follicular cavity; IGL, inner granulosa layer; MF, mature follicle; PF, premature follicle; SF, secondary follicle. Scale bars: $100 \mu \mathrm{m}$ [from Ref. (79)]. pituitary cells has been reported in different species. Indeed, incubation of gonadotrophic cells with whole semen, SP or purified $\beta$-NGF induced a significant increase in $\mathrm{LH}$ secretion $(39,64,65)$. The obtained effect seems to be not mediated by $\mathrm{GnRH}$ receptors since the $\mathrm{LH}$ secretion from rat pituitary cells was not impaired by an anti-GnRH antibody in the media (64). These in vitro results indicate that $\beta$-NGF plays its role independently from $\mathrm{GnRH}$ as also supported by the presence of $\beta$-NGF TrkA receptors in gonadotrophs cells (66). Furthermore, in vivo studies conducted in llamas and alpaca showed that LH secretion was more sustained in females treated with SP or purified $\beta$-NGF than in the ones treated with GnRH (13, $31,34,40)$. Furthermore, $\beta$-NGF pretreatment of llamas with a GnRH antagonist (Cetrorelix) suppressed the $\beta$-NGF- and GnRH-induced LH secretion and subsequent ovulation, thus demonstrating that circulating $\beta$-NGF is acting upstream of the pituitary GnRH receptors (67).

In rat, $\beta$-NGF receptors are found in the hypothalamus, particularly in the medial preoptic area (POA), arcuate nucleus, and ventral premammillary nucleus $(68,69)$. In llama also, Adams et al. (36) reported that $\beta$-NGF and TrkA are present in the hypothalamus. Other studies have provided indirect evidences for the involvement of hypothalamus in the
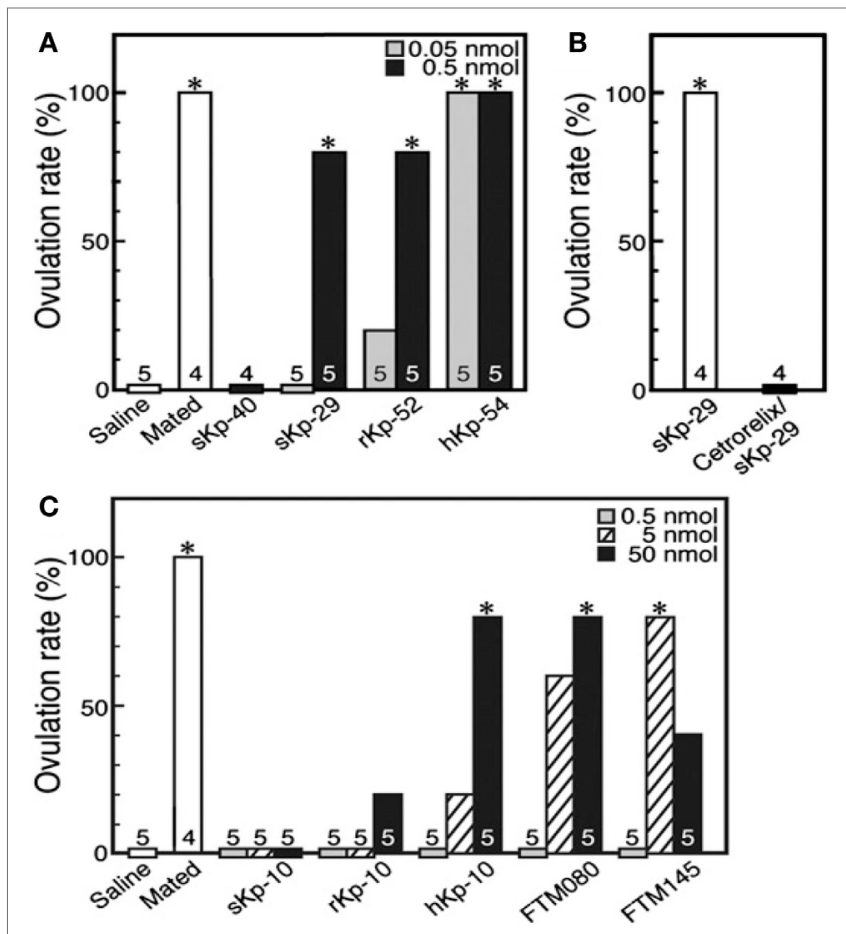

FIGURE 7 | The ovulation rate in musk shrews, an induced ovulator, under the effect of various kisspeptins and GPR54 agonists. (A) Females mated or injected with saline or sKp-40 (0.5 nmol per animal) or with sKp-29, rKp-52, or hKp-54 (0.05 or $0.5 \mathrm{nmol}$ per animal). ${ }^{\star} P<0.05$. (B) Effect of cetrorelix, a gonadotropin-releasing hormone antagonist, on sKp-29-induced ovulation. ${ }^{\star} P<0.05$. (C) Females mated or injected with saline, sKp-10, rKp-10, hKp-10, or the GPR54 agonists FTM080 or FTM145 (0.5, 5, or $50 \mathrm{nmol}$ per animal). ${ }^{*} P<0.05$. Number of animals treated are shown over each column [from Ref. (79)]. 
$\beta$-NGF-induced LH release. The study conducted by Silva et al. (70) investigated the role of estradiol (for which a high concentration in the hypothalamus is required to induce the LH surge) in mediating $\beta$-NGF effects. Indeed, authors showed that the
$\beta$-NGF-induced LH surge was suppressed in ovariectomized female llamas but partly restored by estradiol administration, therefore indicating that $\beta$-NGF effect requires the hypothalamic action of estradiol.

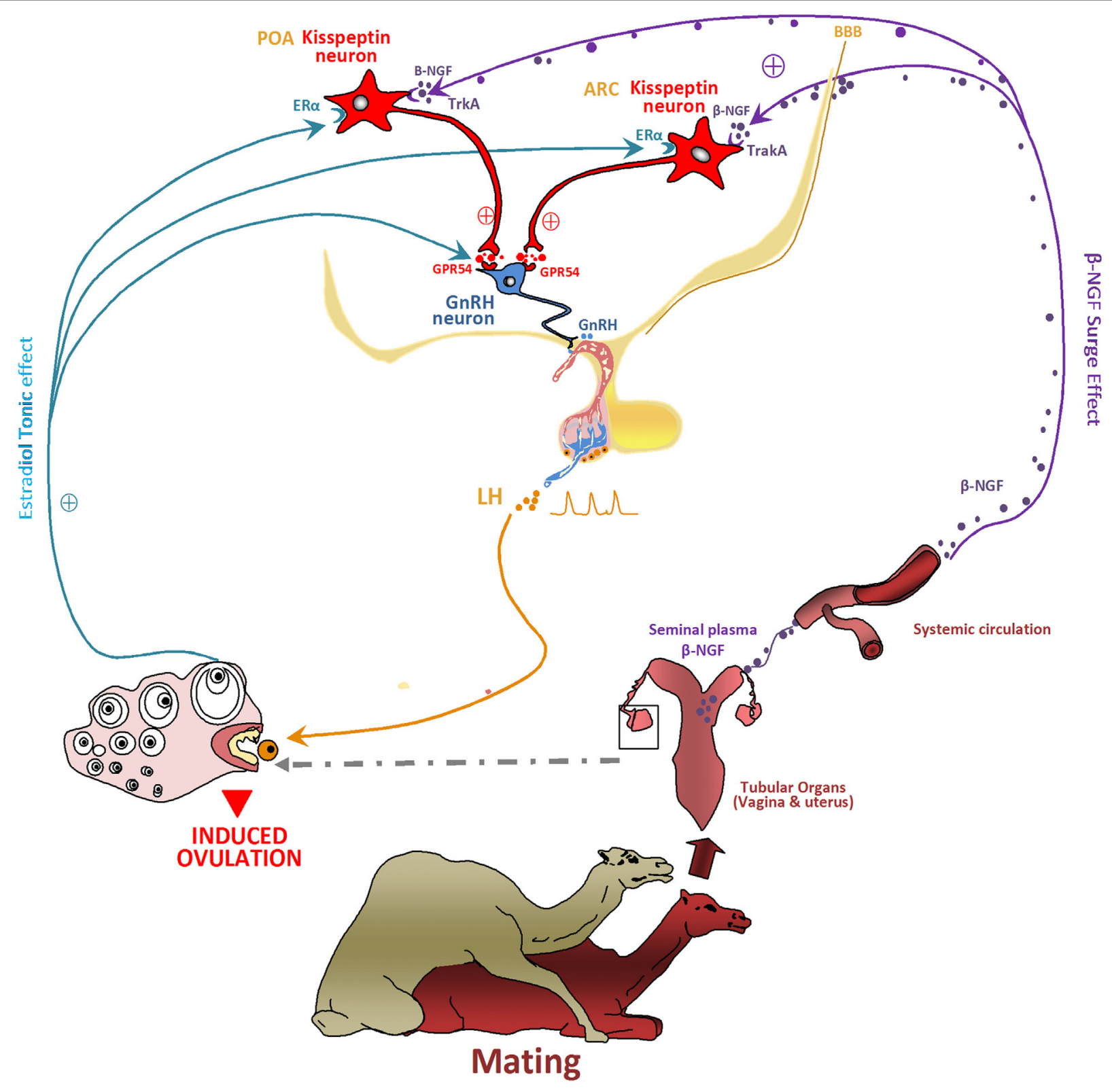

FIGURE 8 | Proposed model hypothesis for kisspeptin (Kp) neurons involvement in the $\beta$-NGF initiation of the preovulatory luteinizing hormone (LH) surge and induced ovulation following mating in camelids. The figure shows how Kp neurons may act as central processors for relaying $\beta$-NGF/matting signals to gonadotropin-releasing hormone $(\mathrm{GnRH})$ neurons activation. Following coitus, the $\beta$-NGF of the seminal plasma is absorbed through the genital mucosa within the general circulation and conveyed toward the central nervous system. $\beta$-NGF crosses probably the blood-brain barrier (BBB) to reach the hypothalamus at the level of preoptic area (POA) and arcuate nucleus (ARC) where it binds the TrkA receptor expressed by Kp neurons. By activating Kp neurons, $\beta$-NGF induces a sequence of neuroendocrine events leading to the ovulation: Kp released at axonal ends binds the GPR54 receptors located on the GnRH neurons and stimulate the release of $\mathrm{GnRH}$. The $\mathrm{GnRH}$ on the other hand stimulates the release of a pulse of $\mathrm{LH}$, which leads to the rupture of the dominant follicle and thus induced the ovulation. In such seasonal breeders, Kp would be also responsible, as for other species, for the seasonal stimulating of the neuroendocrine reproductive axis. The known steroids positive feedback responsible of ovulation in spontaneous ovulators is lacking in reflex ovulators, However, estradiol seems to play an important role for inducing ovulation in such species as discussed before in the musk shrew and llama. It seems to be involved in $\beta$-NGF effect. Estradiol would be responsible of a tonic effect while the $\beta$-NGF exerts a surge effect. By binding its receptor ER $\alpha$ located on Kp neurons, estradiol promotes the neuronal activation and the release of $\mathrm{Kp}$. The effect of Kp would be also distinct and unlike for the two Kp populations of POA and ARC. 
It is now well established that the main hypothalamic sites of action of estradiol are Kp neurons. Since the discovery in 2003 that human (71) and mice (72) lacking functional Kp receptor (Kiss1r) are infertile, numerous studies have demonstrated the critical role of this neuropeptide in pubertal development and adult reproduction [see Ref. (1) for review]. Kp neurons have been found in the hypothalamus of all mammals investigated so far, and they project their fibers mainly to the GnRH cell bodies, in the POA, and nerve terminals, in the median eminence (73-77). All Kp neurons express estradiol receptors, and they are now considered as the main central sites for both the positive and negative (according the hypothalamic nuclei where Kp neurons are located) feedback effects of estradiol. Kp is extremely potent to trigger GnRH release and the downstream LH and FSH secretion, and it is now accepted that $\mathrm{Kp}$ is responsible for the induction of the preovulatory LH surge in female mammals (78).

Recent studies have investigated the putative role of $\mathrm{Kp}$ in induced ovulators. In the musk shrew, the number of Kp expressing neurons is regulated by estradiol, and injection of exogenous suncus Kp (sKp-29) was found to induce follicular maturation and ovulation similarly than matting [Figure 6; (79)]. Furthermore, Kiss1r mRNA was found in the musk shrew hypothalamus and pretreatment with a GnRH antagonist completely blocked the sKp-29-induced ovulation (Figure 7) suggesting that Kp induces ovulation via an activation of GnRH neurons.

From these data, it is tempting to speculate that Kp neurons may be one of the central $\beta$-NGF targets for the mating-induced ovulation. Indeed, in the musk shrew, mating induces a large increase in c-Fos expression (marker of neuronal activation) in hypothalamic Kp neurons (79). This finding indicates that $\beta$-NGF may act through the hypothalamic Kp neurons to elicit the preovulatory LH surge and may be similarly important in the spontaneous and induced ovulators to induce the LH surge and ovulation. This hypothesis raises the question of the route by which the mating-induced increase in circulating $\beta$-NGF reaches the female hypothalamus. Adams et al. (36) suggested that the cerebrospinal fluid may be a potential route for the central effect

\section{REFERENCES}

1. Pinilla L, Aguilar E, Dieguez C, Millar RP, Tena-Sempere M. Kisspeptins and reproduction: physiological roles and regulatory mechanisms. Physiol Rev (2012) 92(3):1235-316. doi:10.1152/physrev.00037.2010

2. Espey LL, Lipner H. Ovulation. 2nd ed. In: Knobil E, Neill JD, editors. The Physiology of Reproduction. New York: Raven Press (1994). p. 725-80.

3. Espey LL. Ovulation as an inflammatory reaction - a hypothesis. Biol Reprod (1980) 22(1):73-106. doi:10.1095/biolreprod22.1.73

4. Takahashi T, Ohnishi J. Molecular mechanism of follicle rupture during ovulation. Zoolog Sci (1995) 12(4):359-65. doi:10.2108/zsj.12.359

5. Tanghe S, Soom AV, Nauwynck H, Coryn M, De Kruif A. Minireview: functions of the cumulus oophorus during oocyte maturation, ovulation, and fertilization. Mol Reprod Dev (2002) 61(3):414-24. doi:10.1002/mrd.10102

6. Bakker J, Baum MJ. Neuroendocrine regulation of GnRH release in induced ovulators. Front Neuroendocrinol (2000) 21(3):220-62. doi:10.1006/frne. 2000.0198

7. Beker JB, Breedlove SM, Crews D, McCarthy MM. Behavioral Endocrinology. Cambridge, MA: MIT Press (2002).

8. Fernandez-Baca S, Madden DHL, Novoa C. Effect of different mating stimuli on induction of ovulation in the alpaca. J Reprod Fertil (1970) 22(2):261-7. doi:10.1530/jrf.0.0220261 of $\beta$-NGF, an hypothesis requiring that circulating $\beta$-NGF crosses the blood-brain barrier (BBB). Indeed, Loy et al. (80) observed a specific uptake of intravenously injected ${ }^{125}$-NGF into different parts of central nervous system $1 \mathrm{~h}$ after injection, an observation further confirmed in mice (81) and rabbits (82). Thus, these data indicate that $\beta$-NGF, released in the general circulation following induced ovulator mating, can cross the $\mathrm{BBB}$, and it therefore may reach hypothalamic cells, possibly $\mathrm{Kp}$ or $\mathrm{GnRH}$ neurons to further trigger the preovulatory LH surge (Figure 8).

Taken together, these results have demonstrated the pivotal role played by $\beta$-NGF in the modulation and activation of the reproductive axis of induced ovulators. However, its site and mechanism of actions are far from being understood. In this regard, the Kp hypothalamic neurons appear as an interesting putative target, an hypothesis that now required further investigation in induced ovulators, especially camelids.

\section{AUTHOR CONTRIBUTIONS}

KA and VS conceived and designed the hypothesis. KA, NB, HA, and VS wrote and approved the final review.

\section{ACKNOWLEDGMENTS}

The authors are grateful to the publishers, BioMed Central (Figures 3 and 4; Tables 1 and 2), PNAS (Figures 6 and 7), and Wiley (Figure 2) for graciously granting the permission for the reuse of the respective figures and tables. The permission of the reuse of Figures 1 and 5 is obtained from Oxford University Press under the license number, respectively, 4125590091129 and 4125590900910 .

\section{FUNDING}

Funding was provided by PHC Toubkal Program no. TBK: 15/01 and the National Center of Scientific and Technical Research (CNRST: URAC-49), Morocco.

9. Jöchle W. Current research in coitus-induced ovulation: a review. J Reprod Fertil Suppl (1975) 22:165-207.

10. Chen BX, Yuen ZX, Pan GW. Semen-induced ovulation in the bactrian camel (Camelus bactrianus). J Reprod Fertil (1985) 73:335-9. doi:10.1530/ jrf.0.0740335

11. Xu YS, Wang HY, Zeng GQ, Jiang GT, Gao HY. Hormone concentrations before and after semen-induced ovulation in the Bactrian camel (Camelus bactrianus). J Reprod Fertil (1985) 74(2):341-6. doi:10.1530/jrf.0.0740341

12. Zhao XX, Li XL, Chen BX. Isolation of ovulation-inducing factors in the seminal plasma of Bactrian camels (Camelus bactrianus) by DEAE-cellulose chromatography. Reprod Dom Anim (2001) 36(3-4):177-81. doi:10.1046/j. 1439-0531.2001.d01-33.x

13. Adams GP, Ratto MH, Huanca W, Singh J. Ovulation inducing factor in the seminal plasma of alpacas and llamas. Biol Reprod (2005) 73(3):452-7. doi:10.1095/biolreprod.105.040097

14. Ratto MH, Huanca W, Singh J, Adams GP. Local versus systemic effect of ovulation-inducing factor in the seminal plasma of alpacas. Reprod Biol Endocrinol (2005) 3:29. doi:10.1186/1477-7827-3-29

15. Ratto MH, Huanca W, Singh J, Adams GP. Comparison of the effect of ovulation-inducing factor (OIF) in the seminal plasma of llamas, alpacas and bulls. Theriogenology (2006) 66(5):1102-6. doi:10.1016/j.theriogenology. 2006.02.050 
16. Ratto MH, Huanca W, Adams GP. Ovulation-inducing factor: a protein component of llama seminal plasma. Reprod Biol Endocrinol (2010) 8:44. doi:10.1186/1477-7827-8-44

17. Ratto MH, Leduc YA, Valderrama XP, van Straaten KE, Delbaere LT, Pierson RA, et al. The nerve of ovulation-inducing factor in semen. Proc Natl Acad Sci U S A (2012) 109(37):15042-7. doi:10.1073/pnas.1206273109

18. Rodriguez AR. Ovulation en las alpacas [Bachelor Thesis]. Lima: Faculty of Veterinary Medicine, National University of San Marcos (1959).

19. San-Martin M, Copaira M, Zuniga J, Rodreguez R, Bustinza G, Acosta L. Aspects of reproduction in the alpaca. J Reprod Fertil (1968) 16(3):395-9. doi:10.1530/jrf.0.0160395

20. Shalash MR, Nawito M. Some reproductive aspects in the female camel. Proceeding of the 5th International Congress of Animal Reproduction and Artificial Insemination. (Vol. 2), Trento (1964). p. 263-7.

21. Berland MA, Ulloa-Leal C, Barría M, Wright H, Dissen GA, Silva ME, et al. Seminal plasma induces ovulation in llamas in the absence of a copulatory stimulus: role of nerve growth factor as an ovulation-inducing factor. Endocrinology (2016) 157(8):3224-32. doi:10.1210/en.2016-1310

22. Marie M, Anouassi A. Induction of luteal activity and progesterone secretion in the nonpregnant one-humped camel (Camelus dromedarius). J Reprod Fertil (1987) 80(1):183-92. doi:10.1530/jrf.0.0800183

23. Anouassi A, Adnani M, Rae EL. Successful pregnancy following AI in camel requires induction of ovulation. Proceedings of the First International Camel Symposium. Dubai, United Arab Emirates: World Trade Centre (1992). p. $175-8$.

24. Moslah M, Minoia P, Lacalandra GM, Khorchani T, Zamilli A. Hormonal stimulation of libido and reproductive function in the male dromedary camel: clinical observations. Proceedings of the First International Camel Conference. Dubai, United Arab Emirates (1992). p. 173-4.

25. Skidmore JA, Billah M, Allen WR. The ovarian follicular wave pattern and induction of ovulation in the mated and non-mated one humped camel (Camelus dromedarius). J Reprod Fertil (1996) 106(2):185-92. doi:10.1530/ jrf.0.1060185

26. Tibary A, Anouassi A. Artificial breeding and manipulation of reproduction in camelidae. In: Tibary A, Anouassi A, editors. Theriogenology in Camelidae: Anatomy, Physiology, Pathology and Artificial Breeding. Rabat, Morocco: Actes Editions (1997). p. 413-4.

27. Skidmore JA. Reproduction in dromedary camels: an update. Anim Reprod (2005) 2(3):161-71.

28. Bravo PW, Fowler ME, Stabenfeldt GH, Lasley BL. Endocrine responses in the llama to copulation. Theriogenology (1990) 33(4):891-9. doi:10.1016/ 0093-691X(90)90824-D

29. Bravo PW, Stabenfeldt GH, Lasley BL, Fowler ME. The effect of ovarian follicle size on pituitary and ovarian responses to copulation in domesticated South American Camelids. Biol Reprod (1991) 45(4):553-9. doi:10.1095/ biolreprod45.4.553

30. Fatnassi M, Cebrián-Pérez JA, Salhi I, Pérez-Pé R, Seddik MM, Casao A, et al. Identification of beta-nerve growth factor in dromedary camel seminal plasma and its role in induction of ovulation in females. Emirates J Food Agric (2017) 29(4):293-9. doi:10.9755/ejfa.2016-11-1585

31. Tanco VM, Ratto MH, Lazzarotto M, Adams GP. Dose-response of female llamas to ovulation-inducing factor from seminal plasma. Biol Reprod (2011) 85(3):452-6. doi:10.1095/biolreprod.111.091876

32. Silva ME, Colazo MG, Ratto MH. GnRH dose reduction decreases pituitary LH release and ovulatory response but does not affect corpus luteum (CL) development and function in llamas. Theriogenology (2012) 77(9):1802-10. doi:10.1016/j.theriogenology.2011.12.024

33. Stuart CC, Vaughan JL, Kershaw-Young CM, Wilkinson J, Bathgate R, de Graaf SP. Effects of varying doses of $\beta$-nerve growth factor on the timing of ovulation, plasma progesterone concentration and corpus luteum size in female alpacas (Vicugna pacos). Reprod Fertil Dev (2015) 27(8):1181-6. doi:10.1071/RD14037

34. Ulloa-Leal C, Bogle OA, Adams GP, Ratto MH. Luteotrophic effect of ovulation-inducing factor/nerve growth factor present in the seminal plasma of llamas. Theriogenology (2014) 81(8):1101-7. doi:10.1016/j.theriogenology. 2014.01.038
35. Fernandez A, Ulloa-Leal C, Silva M, Norambuena C, Adams GP, Guerra M, et al. The effect of repeated administrations of llama ovulation-inducing factor (OIF/B-NGF) during the periovulatory period on corpus luteum development and function in llamas. Anim Reprod Sci (2014) 149(3-4):345-52. doi:10.1016/j.anireprosci.2014.08.001

36. Adams GP, Ratto MH, Silva ME, Carrasco RA. Ovulation-inducing factor (OIF/B-NGF) in seminal plasma: a review and update. Reprod Dom Anim (2016) 51(2):4-17. doi:10.1111/rda.12795

37. Zhao XX, Pan GW, Huang YM. Studies on the ovulation-inducing factors in the seminal plasma of Bactrian camel. In: Saint-Martin G, editor. Proceeding of the Workshop "Is it Possible to Improve the Reproductive Performance of the Camel?". Paris: CIRAD-EMVT (1990). p. 197-208.

38. Pan G, Chen Z, Liu X, Li D, Xie Q, Ling F. Isolation and purification of the ovulation-inducing factor from seminal plasma of the Bactrian camel (Camelus bactrianus). Theriogenology (2001) 55(9):1863-79. doi:10.1016/ S0093-691X(01)00528-3

39. Li X, Zhao X. Separation and purification of ovulation-inducing factors in the seminal plasma of the Bactrian camel (Camelus bactrianus). Vet Res Commun (2004) 28(3):235-45. doi:10.1023/B:VERC.0000017370.74401.be

40. Ratto MH, Delbaere LTJ, Leduc YA, Pierson RA, Adams GP. Biochemical isolation and purification of ovulation-inducing factor (OIF) in seminal plasma of llamas. Reprod Biol Endocrinol (2011) 9:24. doi:10.1186/1477-7827-9-24

41. Kershaw-Young CM, Druart X, Vaughan J, Maxwell WMC. $\beta$-Nerve growth factor is a major component of alpaca seminal plasma and induces ovulation in female alpacas. Reprod Fertil Dev (2012) 24(8):1093-7. doi:10.1071/ RD12039

42. Kumar S, Sharma VK, Singh S, Hariprasad GR, Mal G, Srinivasan A, et al. Proteomic identification of camel seminal plasma: purification of $\beta$-nerve growth factor. Anim Reprod Sci (2013) 136(4):289-95. doi:10.1016/j. anireprosci.2012.11.001

43. Silva ME, Niño A, Guerra M, Letelier C, Valderrama XP, Adams GP, et al. Is an ovulation-inducing factor (OIF) present in the seminal plasma of rabbits? Anim Reprod Sci (2011) 127(3-4):213-21. doi:10.1016/j.anireprosci.2011.08.004

44. Maranesi M, Zerani M, Leonardi L, Pistilli A, Arruda-Alencar J, Stabile AM, et al. Gene expression and localization of NGF and its cognate receptors NTRK1 and NGFR in the sex organs of male rabbits. Reprod Domest Anim (2015) 50(6):918-25. doi:10.1111/rda.12609

45. Garcia-Garcia RM, Masdeu M, Sánchez-Rodríguez A, Bautista JM, AriasAlvarez M, Lorenzo PL, et al. Expression of $\beta$-nerve growth factor in rabbit male tract and seminal plasma. Anim Reprod (2015) 12(3):562.

46. Masdeu M, Garcia-Garcia RM, Cardinali R, Millan P, Arias Alvarez M, Castellini C, et al. 271 induction of ovulation in rabbit does using purified nerve growth factor and camel seminal plasma. Reprod Fertil Dev (2014) 27(1):224-5. doi:10.1071/RDv27n1Ab271

47. Cervantes MP, Palomino JM, Adams GP. In vivo imaging in the rabbit as a model for the study of ovulation-inducing factors. Lab Anim (2015) 49(1):1-9. doi:10.1177/0023677214547406

48. Dissen GA, Romero C, Hirshfield AN, Ojeda SR. Nerve growth factor is required for early follicular development in the mammalian ovary. Endocrinology (2001) 142(5):2078-86. doi:10.1210/endo.142.5.8126

49. Aloe L, Rocco ML, Bianchi P, Manni L. Nerve growth factor: from the early discoveries to the potential clinical use. J Transl Med (2012) 10:239. doi:10.1186/1479-5876-10-239

50. Harper GP, Barde YA, Burnstock G, Carstairs JR, Dennison ME, Suda K, et al. Guinea pig prostate is a rich source of nerve growth factor. Nature (1979) 279(5709):160-2. doi:10.1038/279160a0

51. Harper GP, Theonen H. The distribution of nerve growth factor in the male sex organs of mammals. J Neurochem (1980) 34(4):893-903. doi:10.1111/ j.1471-4159.1980.tb04615.x

52. Harper GP, Glanville RW, Thoenen $\mathrm{H}$. The purification of nerve growth factor from bovine seminal plasma. Biochemical characterization and partial amino acid sequence. J Biol Chem (1982) 257(14):8541-8.

53. Hofmann HD, Unsicker K. The seminal vesicle of the bull: a new and very rich source of nerve growth factor. Eur J Biochem (1982) 128(2-3):421-6. doi:10.1111/j.1432-1033.1982.tb06981.x 
54. Ayer-LeLievre C, Olson L, Ebendal T, Hallböök F, Persson H. Nerve growth factor mRNA and protein in the testis and epididymis of mouse and rat. Proc Natl Acad Sci U S A (1988) 85(8):2628-32. doi:10.1073/pnas.85. 8.2628

55. Bogle OA, Ratto MH, Adams GP. Evidence for the conservation of biological activity of ovulation-inducing factor in seminal plasma. Reproduction (2011) 142(2):277-83. doi:10.1530/REP-11-0042

56. Tanco VM, Van Steel andt MD, Ratto MH, Adams GP. Effect of purified llama ovulation-inducing factor (OIF) on ovarian function in cattle. Theriogenology (2012) 78(5):1030-9. doi:10.1016/j.theriogenology.2012.03.036

57. Dissen GA, Hill DF, Costa ME, Les Dees CW, Lara HE, Ojeda SR. A role for trkA nerve growth factor receptors in mammalian ovulation. Endocrinology (1996) 137(1):198-209. doi:10.1210/endo.137.1.8536613

58. Mayerhofer A, Dissen GA, Parrott JA, Hill DF, Mayerhofer D, Garfield RE, et al. Involvement of nerve growth factor in the ovulatory cascade: trkA receptor activation inhibits gap junctional communication between thecal cells. Endocrinology (1996) 137(12):5662-70. doi:10.1210/endo.137.12.8940397

59. Dissen GA, Parrott JA, Skinner MK, Hill DF, Costa ME, Ojeda SR. Direct effects of nerve growth factor on thecal cells from antral ovarian follicles. Endocrinology (2000) 141(12):4736-50. doi:10.1210/endo.141.12. 7850

60. Abir R, Fisch B, Jin S, Barnnet M, Ben-Haroush A, Felz C, et al. Presence of NGF and its receptors in ovaries from human fetuses and adults. Mol Hum Reprod (2005) 4:229-36. doi:10.1093/molehr/gah164

61. Canóón-Beltrán K, Cajas YN, Garcia-Garcia RM, Lorenzo PL, Carrera R, Rebollar PG, et al. Expression of $\beta$-nerve growth factor in rabbit male tract and seminal plasma. Proceedings of the 29th Annual Meeting of the Brazilian Embryo Technology Society (SBTE). Gramado, Rio Grande do Sul: 31st Meeting of the European Embryo Transfer Association (AETE) (2015).

62. Carrasco R, Singh J, Adams GP. The dynamics of trkA expression in the bovine ovary are associated with a luteotrophic effect of ovulation-inducing factor/ nerve growth factor (OIF/ß-NGF). Reprod Biol Endocrinol (2016) 14(1):47. doi:10.1186/s12958-016-0182-9

63. Bravo PW, Moscoso J, Ordonez C, Alarcon V. Transport of spermatozoa and ova in female alpaca. Anim Reprod Sci (1996) 43:173-9. doi:10.1016/ 0378-4320(95)01465-9

64. Paolicchi F, Urquieta B, Del Valle L, Bustos-Obregón E. Biological activity of the seminal plasma of alpacas: stimulus for the production of LH by pituitary cells. Anim Reprod Sci (1999) 54(3):203-10. doi:10.1016/S0378-4320(98) 00150-X

65. Bogle OA, Ratto MH, Adams GP. Ovulation-inducing factor (OIF) induces LH secretion from pituitary cells. Anim Reprod Sci (2012) 133(1-2):117-22. doi:10.1016/j.anireprosci.2012.06.006

66. Patterson JC, Childs GV. Nerve growth factor and its receptor in the anterior pituitary. Endocrinology (1994) 135(4):1689-96. doi:10.1210/endo.135. 4.7925134

67. Silva ME, Smulders JP, Guerra M, Valderrama XP, Letelier C, Adams GP, et al. Cetrorelix suppresses the preovulatory LH surge and ovulation induced by ovulation-inducing factor (OIF) present in llama seminal plasma. Reprod Biol Endocrinol (2011) 9:74. doi:10.1186/1477-7827-9-74

68. Pioro EP, Cuello AC. Distribution of nerve growth factor receptor-like immunoreactivity in the adult rat central nervous system. Effect of colchicine and correlation with the cholinergic system - I. Forebrain. Neuroscience (1990) 34(1):57-87. doi:10.1016/0306-4522(90)90305-N

69. Gibbs RB, Plaff DW. In situ hybridization detection of trka mRNA in brain: distribution, colocalization with p75NGFR and up-regulation by nerve growth factor. J Comp Neurol (1994) 341(3):324-39. doi:10.1002/cne.903410304

70. Silva ME, Recabarren MP, Recabarren SE, Adams GP, Ratto MH. Ovarian estradiol modulates the stimulatory effect of ovulation inducing factor (OIF) on pituitary LH secretion in llamas. Theriogenology (2012) 77(9):1873-82. doi:10.1016/j.theriogenology.2012.01.004

71. De Roux N, Genin E, Carel J-C, Matsuda F, Chaussain J-L, Milgrom E. Hypogonadotropic hypogonadism due to loss of function of the KiSS1-derived peptide receptor GPR54. Proc Natl Acad Sci U S A (2003) 100(19):10972-6. doi:10.1073/pnas.1834399100

72. Seminara SB, Messager S, Chatzidaki EE, Thresher RR, Acierno JS Jr, Shagoury JK, et al. The GPR54 gene as a regulator of puberty. N Engl J Med (2003) 349(17):1614-27. doi:10.1056/NEJMoa035322

73. Clarkson J, Herbison AE. Postnatal development of kisspeptin neurons in mouse hypothalamus; sexual dimorphism and projections to gonadotropinreleasing hormone neurons. Endocrinology (2006) 147(12):5817-25. doi:10.1210/ en.2006-0787

74. d'Anglemont de Tassigny X, Fagg LA, Carlton MB, Colledge WH. Kisspeptin can stimulate gonadotropin-releasing hormone $(\mathrm{GnRH})$ release by a direct action at GnRH nerve terminals. Endocrinology (2008) 149(8):3926-32. doi:10.1210/en.2007-1487

75. Clarkson J, d'Anglemont de Tassigny X, Colledge WH, Caraty A, Herbison AE. Distribution of kisspeptin neurones in the adult female mouse brain. J Neuroendocrinol (2009) 21(8):673-82. doi:10.1111/j.1365-2826.2009.01892.x

76. Desroziers E, Mikkelsen J, Simonneaux V, Keller M, Tillet Y, Caraty A, et al. Mapping of kisspeptin fibres in the brain of the pro-oestrous rat. J Neuroendocrinol (2010) 22(10):1101-12. doi:10.1111/j.1365-2826.2010. 02053.x

77. Matsuyama S, Ohkura S, Mogi K, Wakabayashi Y, Mori Y, Tsukamura H, et al. Morphological evidence for direct interaction between kisspeptin and gonadotropin-releasing hormone neurons at the median eminence of the male goat: an immunoelectron microscopic study. Neuroendocrinology (2011) 94(4):323-32. doi:10.1159/000331576

78. Smith JT, Cunningham MJ, Rissman EF, Clifton DK, Steiner RA. Regulation of Kiss1 gene expression in the brain of the female mouse. Endocrinology (2005) 146(9):3686-92. doi:10.1210/en.2005-0323

79. Inoue N, Sasagawa K, Ikai K, Sasaki Y, Tomikawa J, Oishi S, et al. Kisspeptin neurons mediate reflex ovulation in the musk shrew (Suncus murinus). Proc Natl Acad Sci U S A (2011) 108(42):17527-32. doi:10.1073/ pnas. 1113035108

80. Loy R, Taglialatela G, Angelucci L, Heyer D, Perez-Polo R. Regional CNS uptake of blood-borne nerve growth factor. J Neurosci Res (1994) 39(3): 339-46. doi:10.1002/jnr.490390311

81. Pan W, Banks WA, Kastin JA. Permeability of the blood-brain barrier to neurotrophins. Brain Res (1998) 788(1-2):87-94. doi:10.1016/S0006-8993(97) 01525-4

82. Berland M, Guerra M, Bogle OA, Vio K, Adams GP, Ratto MH. 107 detection of biotinylated-ovulation-inducing factor (OIF) in cerebrospinal fluid and its ability to induce ovulation. Reprod Fertil Dev (2013) 25(1):201. doi:10.1071/ RDv25n1Ab107

Conflict of Interest Statement: The authors declare that the research was conducted in the absence of any commercial or financial relationships that could be construed as a potential conflict of interest.

Copyright $\odot 2017$ El Allali, El Bousmaki, Ainani and Simonneaux. This is an openaccess article distributed under the terms of the Creative Commons Attribution License (CC BY). The use, distribution or reproduction in other forums is permitted, provided the original author(s) or licensor are credited and that the original publication in this journal is cited, in accordance with accepted academic practice. No use, distribution or reproduction is permitted which does not comply with these terms. 